\title{
Production, Competition Indices, and Nutritive Values of Setaria splendida, Centrosema pubescens, and Clitoria ternatea in Mixed Cropping Systems in Peatland
}

\author{
A. Ali ${ }^{a, d, *}$, L. Abdullah ${ }^{b}$, P. D. M. H. Karti ${ }^{b}$, M. A. Chozin ${ }^{c}$, \& D. A. Astuti ${ }^{b}$ \\ aMajor Program of Animal Nutrition and Feed Science, Graduate School, Bogor Agricultural University \\ ${ }^{b}$ Department of Nutrition and Feed Technology, Faculty of Animal Science, Bogor Agricultural University \\ Jln. Agatis, Kampus IPB Darmaga Bogor 16680, Indonesia \\ 'Department of Agronomy and Horticulture, Faculty of Agriculture, Bogor Agricultural University \\ Jln. Meranti Kampus IPB Darmaga, Bogor 16680, Indonesia \\ ${ }^{d}$ Department of Animal Science, Faculty of Agriculture and Animal Science, UIN Suska Riau \\ Jln. H. R. Soebrantas No.155 KM 18, Simpang Baru Panam, Pekanbaru 28293, Indonesia \\ (Received 11-09-2013; Reviewed 09-10-2013; Accepted 03-12-2013)
}

\begin{abstract}
This research was conducted to evaluate production, different competition indices and nutritive value of Setaria splendida, Centrosema pubescens, and Clitoria ternatea in monoculture and mix cropping system on peat soil land. The experiment was set up in a randomized complete block design with five treatments and three replications. The five treatments were: S. splendida sole cropping (SS), C. pubescens sole cropping (CP), C. ternatea sole cropping (CT), S. splendida and C. pubescens mix cropping (SS/CP) and S. splendida/C. ternatea mix cropping (SS/CT). The DM yield of S. splendida in mixed cropping with $C$. pubescens increased $43.4 \%$ and in mix cropping with $C$. ternatea increased $15.7 \%$ compared to sole $S$. splendida. The value of land equivalent ratio of SS/CP $\left(\mathrm{LER}_{\mathrm{SS} / \mathrm{CP}}\right)$ was $>1$. The $\mathrm{LER}_{\mathrm{SS} / \mathrm{CT}}$ value was $<1$. The crowding coefficient value of $S$. splendida $\left(\mathrm{K}_{\mathrm{SS}}\right)$ was higher than $\mathrm{K}_{\mathrm{CP}}$ and $\mathrm{K}_{\mathrm{CT}}$. The total value of $\mathrm{K}_{\mathrm{SS} / \mathrm{CP}}$ and $\mathrm{K}_{\mathrm{SS} / \mathrm{CT}}$ were $>1$. The competition ratio (CR) values of $S$. splendida in both mix cropping were $>1$. The agressivity (A) values of $S$. splendida in both mix cropping were positive. The crude protein, NDF and ADF content of forage were not affected by mix cropping system. In conclusion, mix cropping in peatland do not affect productivity and nutritive value of $S$. splendida, C. pubescens, and C. ternatea. S. splendida is more effective in exploiting environmental resources when intercropped with $C$. pubescens compared to $C$. ternatea on peatland.
\end{abstract}

Key words: cropping system, forage, production, quality

\section{ABSTRAK}

Penelitian bertujuan untuk mengevaluasi produksi, indeks kompetisi yang berbeda dan nilai nutrisi Setaria splendida, Centrosema pubescens, dan Clitoria ternatea dengan sistem pertanaman tunggal dan campuran di lahan gambut. Penelitian menggunakan rancangan acak kelompok yang terdiri atas 5 perlakuan dan 3 ulangan, yaitu S. splendida yang ditanam tunggal (SS), C. pubescens yang ditanam tunggal (CP), C. ternatea yang ditanam tunggal (CT), S. splendida dan C. pubescens yang ditanam campuran (SS/CP), serta S. splendida dan C. ternatea yang ditanam campuran (SS/CT). Produksi bahan kering $S$. splendida yang ditanam campuran dengan $C$. pubescens meningkat $43.4 \%$ dan pertanaman campuran dengan $C$. ternatea meningkat $15.7 \%$ dibandingkan pertanaman tunggal. Nilai land equivalent ratio SS/CP $\left(\mathrm{LER}_{\mathrm{S} / \mathrm{CP}}\right)$ adalah $>1$. $\mathrm{LER}_{\mathrm{SS} / \mathrm{CT}}$ adalah $<1$. Nilai crowding coefficient (K) S. splendida $\left(\mathrm{K}_{\mathrm{SS}}\right)$ adalah lebih tinggi dari $\mathrm{K}_{\mathrm{CP}}$ and $\mathrm{K}_{\mathrm{CT}^{\circ}}$ Nilai total $\mathrm{K}$ plot SS/CP dan SS/CT adalah $>1$. Nilai competition ratio (CR) S. splendida pada kedua pertanaman campuran adalah $>1$. Nilai agressivity (A) S. splendida pada kedua pertanaman campuran adalah positif. Kandungan PK, NDF, dan ADF hijauan tidak terpengaruh oleh sistem pertanaman campuran. Dapat disimpulkan bahwa pertanaman campuran di lahan gambut tidak mempengaruhi produktivitas dan nilai nutrisi S. splendida, C. pubescens, dan C. ternatea. S. splendida lebih kompetitif dan dominan dibanding $C$. pubescens dan C. ternatea di lahan gambut.

Kata kunci: hijauan, sistem penanaman, produksi, kualitas

*Corresponding author:

E-mail: ali_arsyadi@yahoo.com 


\section{INTRODUCTION}

The availability of low cost feed resources is important for successful ruminant production in smallholder farming system in the tropics (Noula et al., 2004). The major limitation of livestock production is the lack of suitable fodder crops that can produce green forage year round (Mutimura \& Everson, 2012). One of the logical approaches to increasing forage production to overcome these problems is pasture improvement by grass and legume mix cropping system (Ajayi et al., 2007). Mix cropping is one of the multiple cropping system, has been practiced by farmer for many years in various ways and most areas (Zhang \& Li, 2003). The advantage of grass/ legume mix cropping in pasture is the possibility of $\mathrm{N}$ addition from the legume to the grass. Depending on the nitrogen content of the soil and the mix of legumes and grasses in a pasture, during the growing season legumes transfer approximately $40 \mathrm{~kg} \mathrm{~N} \mathrm{ha}{ }^{-1}$ to neighbouring plants (Pirhofer-Walzl et al., 2012). Grass/legume mixtures are more sustainable and better overcome unfavorable conditions as compared to their pure cultivation (Peyraud et al., 2009). They are more productive than pure stands and each species contributes the productivity in varying degrees (Vasileva \& Vasilev, 2012).

The mayor limitation of pasture development is the lack of mineral soil for forage. The development pasture can be cultivated in peatland (Organosol). Organosol are formed by progressive accumulation plant materials over time (Agus \& Subiksa, 2008). Limitations in obtaining high forage production in peatland due to differences in the characteristics of peat soil with mineral soil. Naturally, the peat has a low fertility rate because of the low nutrient content, and generally, the peat has a relatively high level of acidity. The purpose of this study was to evaluate the dry matter production, different competition indices and nutritive value of $S$. splendida, C. Pubescens, and C. ternatea in sole and mixed cropping system in peatland.

\section{MATERIALS AND METHODS}

This study was conducted at research farm of Faculty of Agriculture and Animal Science of UIN Suska Riau and Laboratory of Research Center of Biological Resources and Biotechnology, PAU, Bogor Agricultural University from October 2011 to November 2012. The forages investigated were S. splendida (grass), C. Pubescens, and C. ternatea (legumes). The experiment was set up in randomized complete block design with five treatments and three replicates. Five treatments were: $S$. splendida sole cropping (SS), C. pubescens sole cropping (CP), C. ternatea sole cropping (CT), S. splendida/C. pubescens mix cropping (SS/CP) and S. splendida/C. ternatea mix cropping (SS/CT).

\section{Plot, Planting Density and Fertilizing}

This experiment was conducted in peatland type soil (type sapric). The $\mathrm{pH}$ and mineral soil content of experimental land in the form of $\mathrm{N}, \mathrm{C}, \mathrm{C} / \mathrm{N}, \mathrm{K}$ and $\mathrm{P}$ were $5.54,0.14 \%, 7.20 \%, 51.43,2.48 \mathrm{me} / 100 \mathrm{~g}$, and 30.18 ppm, respectively. The size of experimental land was $11.5 \times 17 \mathrm{~m}$ and divided in three blocks. Each block was sub-divided into five plots (each plot size of $2.5 \times 5 \mathrm{~m}$ ), namely SS, CP, CT, SS/CP and SS/CT. The forages were cultivated in September 2011. The plot had a planting density of 50 plants/plot (planting space was $50 \times 50$ $\mathrm{cm}$ ) and was maintained under rain-fed condition. The proportion of grass and legume in mix culture plots was 50 : 50. The basal fertilizer was organic fertilizer (cattle manure) applied at the rate $10 \mathrm{t} / \mathrm{ha}$ and was applied two weeks before planting, and inorganic fertilizers (NPK) at the rate of $50 \mathrm{~kg} / \mathrm{ha} / \mathrm{yr}$ of was applied two weeks after planting (surrounding the plant).

\section{Propagating, Pruning, Harvesting and Sample Procedure}

S. splendida was propagated by cutting while, C. pubescens and $C$. ternatea was propagated by seed. Pruning was done after 2 mo of grown. The forages were trimmed approximately $20 \mathrm{~cm}$ above the ground by using a pair of garden shear. This would allow a new and uniform re-growth from where the experimental samples were later harvested. Grass and legume foliage were harvested six time a year with $60 \mathrm{~d}$ cutting interval. The plants were cut approximately $20 \mathrm{~cm}$ from the ground from each plot ( $n=24$ plant) and directly weighed to determine the fresh yield.

\section{Competition Indices}

The competitive behaviour of component forages in grass/legume mix cropping system was determined in terms of land equivalent ratio (LER), competition ratio (CR), aggressivity (A) according to the methods described by Dhima et al. (2007) and crowding coefficient (K) was estimated according to the methods of Banik et al. (2006). The LER, which measures the effectiveness of mixed cropping in using the environmental resources, compared to sole cropping. The LER values were calculated as follows: $\mathrm{LER}=\left(\mathrm{LER}_{\text {grass }}+\mathrm{LER}_{\text {legume }}\right)$, where LER $_{\text {grass }}=\left(\mathrm{Y}_{\mathrm{gm}} / \mathrm{Y}_{\mathrm{ls}}\right)$, and $\mathrm{LER}_{\text {legume }}^{\stackrel{\text { grass }}{=}}\left(\mathrm{Y}_{\mathrm{lm}} / \mathrm{Y}_{\mathrm{gs}}\right)$, where $\mathrm{Y}_{\mathrm{gs}}$ and $\mathrm{Y}_{\mathrm{ls}}$ are the yields of grass and legume as sole crops respectively, and $Y_{g m}$ and $Y_{l m}$ are the yields of grass and legume as mixtures, respectively. When LER $>1$, there is yield advantage. The CR gives a clear idea about which forage is more competitive in association. The CR values were calculated as: $C R_{\text {grass }}=\left(\mathrm{LER}_{\text {grass }} / \mathrm{LER}_{\text {legume }}\right) \times\left(\mathrm{Z}_{\mathrm{lp}} / \mathrm{Z}_{\mathrm{gp}}\right)$, and $\mathrm{CR}_{\text {legume }}=\left(\mathrm{LER}_{\text {legume }} / \mathrm{LER}_{\text {grass }}\right)^{\text {grass }} \times\left(Z_{\mathrm{gp}} / Z_{\mathrm{lp}}\right)$, where $Z_{\mathrm{gp}}$ and $Z_{\mathrm{lp}}$ are the proportion of grass and legume in the mixture. If $C R$ grass $>1$, grass is more competitive than legume and if the value is $<1$, grass is less competitive than legume. The reverse is true for CR legume. The aggressivity (A) is a measure of competitive relationships between two forages in mixed cropping. This was calculated as follows: $A_{\text {grass }}=\left(Y_{g m} / Y_{g s} \times Z_{g p}\right)-\left(Y_{l m} / Y_{1 s} \times Z_{l p}\right)$ and $A_{\text {legume }}=\left(Y_{l m} / Y_{l s} \times Z_{l p}\right)-\left(Y_{g m}^{g m} / Y_{g s}^{g s} \times Z_{g p}^{g p}\right)$. Thus if $A_{\text {grass }}=$ 0 , both crops are equally competitive, If $\mathrm{A}_{\text {grass }}$ is positive, then the grass is dominant, and if $\mathrm{A}_{\text {grass }}$ is negative, the grass is weak. The relative crowding coefficient $(\mathrm{K})$, which is a measure of the relative dominance of one species over the other in a mixture, was calculated as: $\mathrm{K}=$ 
$\left(\mathrm{K}_{\text {grass }} \times \mathrm{K}_{\text {legume }}\right)$, where $\mathrm{K}_{\text {grass }}=$ Ygm $\times$ Zlp / [(Ygs -Ygm $)$ x $\mathrm{Zgp}]$, and $\mathrm{K}_{\text {legume }}=\mathrm{Ylm} \times \mathrm{Zgp} /[(\mathrm{Yls}-\mathrm{Ylm}) \times \mathrm{Zlp}]$, when the value of $K$ is $>1$, there is yield advantage; when $K$ is $=1$, there is no yield advantage; and, when $K<1$ there is a disadvantage.

\section{Chemical Analysis}

Fresh samples of grass and legume from each plot (about $500 \mathrm{~g}$ ) were dried in air-forced oven at 60 ${ }^{\circ} \mathrm{C}$ for $48 \mathrm{~h}$, and ground to pass through a $1 \mathrm{~mm}$ sieve for chemical analysis. The dry matter (DM) and crude protein $(\mathrm{CP})$ were determined according to the AOAC (2005) procedure. Neutral detergent fiber (NDF) and acid detergent fiber (ADF) are estimated according to the method of Van Soest et al. (1991).

\section{Statistical Analysis}

Data was analyzed by analysis of variance (ANOVA) based on a completely randomized block design with five treatments and three blocks. Comparison of means were considered significantly different at 5\% level $(\mathrm{P}<0.05)$ using Duncan's Multiple Range Test (DMRT).

\section{RESULTS AND DISCUSSION}

\section{Dry Matter Yield of Forages}

Dry matter (DM) yield per plant. The effect of mixed cropping on DM yield per plant (g/yr) of S. splendida, C. pubescens and C. ternatea are shown in Table 1 . The DM yield of $S$. splendida was not significantly increased by mixed cropping. The DM yield of S. splendida in C. pubescens increased $43.4 \%$ and in C. ternatea increased $15.7 \%$ compared sole S. splendida. Intercropped with S. splendida decreased $23.4 \%$ DM yield of C. pubescens. The decreasing in DM yield due to the impact of the interspecific competition which led C. pubescens yield less than those of sole cropping system. Otherwise, $S$. splendida yield higher than those of sole C. pubescens. This condition is regularly found in mixed cropping system. A competition increases yield of dominant species, but decreases yield of sub-ordinate species (Marty et al.,

Table 1. Dry matter (DM) yield (g/year) per plant of S. splendida, C. pubescens, and C. ternatea under monoculture and mixed cropping system

\begin{tabular}{lc}
\hline Forages & DM yield (g/yr) \\
\hline S. splendida & $325 \pm 93$ \\
S. splendida in C. pubescens intercrop & $466 \pm 215$ \\
S. splendida in C. ternatea intercrop & $376 \pm 152$ \\
\hline C. pubescens & $145 \pm 13$ \\
C. pubescens in S. splendida intercrop & $111 \pm 27$ \\
\hline C. ternatea & $205 \pm 77^{\mathrm{a}}$ \\
C. ternatea in S. splendida intercrop & $73 \pm 28^{\mathrm{b}}$ \\
\hline
\end{tabular}

Note: Mean in C. ternatea row with different superscripts differ significantly $(\mathrm{P}<0.05)$
2009). Meanwhile, S. splendida/C. ternatea intercropping was amensalistic, where the DM yield of $C$. ternatea was significantly $(\mathrm{P}<0.05)$ decreased $(64.4 \%)$ as a result of interaction between $S$. splendida and C. ternatea but no significant effect was found on DM yield of S. splendida. Limited growth of $C$. ternatea in mix cropping system may be caused by extended growth of $S$. splendida roots than those of $C$. ternatea. It led extensive nutrient uptake by $S$. splendida from the soil than $C$. ternatea. The negative effect on mixed-culture cropping is a competition in uptaking same nutrient, water, light and the other sources (Forrester et al., 2006; Thorsted et al., 2006).

Dry matter yield per plot. The effect of cropping system (sole and mix cropping) on DM yield per plot are shown in Table 2. It was recorded that SS/CP and SS/CT mixed cropping in peatland did not influence $(\mathrm{P}>0.05)$ the DM yield of forage per plot. Intercopping with $S$. splendida caused the growth of $C$. pubescens and C. ternatea to be lower than the sole crop. Growth of C. pubescens and C. ternatea was hindered by the presence of competition in uptaking nutrient elements in soil (Oseni, 2010). S. splendida grew quickly and forming stolons so that more nutrient were absorbed than C. pubescens and C. ternatea. Intercropping with $C$. pubescens or C. ternatea caused $S$. splendida to grow at a faster rate than the monoculturee, so the lack of production on the mixed culture plot was filled by the production of $S$. splendida. It has been established that the legume component in a grass/legume mixture would improve availability of nutrient in the soil especially nitrogen content through nitrogen fixation (Dhalika et al., 2006; Pozdisek et al., 2011) and via the mineralization of the N-rich legume litter (Marty et al., 2009)

\section{Competition Indices}

Land equivalent ratio (LER). The value of $\mathrm{LER}_{\mathrm{SS} / \mathrm{CP}}$ was $>1$ (1.10) (Table 3). This value indicated that mixed cropping was more effective over sole or mono cropping with regard to the use of environmental sources for plant growth (Mahapatra, 2011). The value of $\mathrm{LER}_{\mathrm{SS} / \mathrm{CT}}$ was $<1$ (0.76) (Table 3) which indicated the disadvantage of mixed cropping over sole $S$. splendida and C. ternatea (Yilmaz et al., 2008; Dhima et al., 2007).

Table 2. Dry matter (DM) yield of forages per plot based on cropping system

\begin{tabular}{llr}
\hline Cropping system & \multicolumn{1}{c}{ Plot } & $\begin{array}{c}\text { DM yield } \\
(\mathrm{t} / \mathrm{ha} / \mathrm{yr})\end{array}$ \\
\hline Monoculture & S. splendida (SS) & $13.01 \pm 3.72^{\mathrm{a}}$ \\
& C. pubescens (CP) & $5.84 \pm 0.53^{\mathrm{b}}$ \\
& C. ternatea (CT) & $8.20 \pm 3.07^{\mathrm{ab}}$ \\
Mixture & SS/CP & $11.55 \pm 3.87^{\mathrm{ab}}$ \\
& SS/CT & $9.00 \pm 3.49^{\mathrm{ab}}$ \\
\hline
\end{tabular}

Note: Mean in the same column with different superscripts differ significantly $(\mathrm{P}<0.05)$. 
Table 3. Competition indices (LER, K, CR and A) of S. splendida (SS), C. pubescens (CP), and C. ternatea (CT) under monoculture and mixed cropping

\begin{tabular}{lllllcc}
\hline \multicolumn{1}{c}{ Competition indices } & \multicolumn{2}{c}{ SS : CP } & Total & SS : CT & Total \\
\hline Land Equivalent Ratio (LER) & 0.72 & 0.38 & 1.10 & 0.58 & 0.18 & 0.76 \\
Crowding Coefficient (K) & 2.53 & 0.62 & 1.56 & 1.38 & 0.22 & 0.30 \\
Competition Ratio (CR) & 1.88 & 0.53 & - & 3.25 & 0.31 & - \\
Aggressivity (A) & 0.67 & -0.67 & - & 0.80 & -0.80 & - \\
\hline
\end{tabular}

Crowding coefficient (K). The value of $\mathrm{K}_{\mathrm{sS}}$ was higher than $\mathrm{K}_{\mathrm{CP}}$ and $\mathrm{K}_{\mathrm{CT}}$ in mixed cropping (Table 3), indicating an advantage of $S$. splendida over the other legume in the mixed cropping system. The presence of legume improved the growth of S. splendida (Mucheru-Muna et al., 2010). Legume root systems did not give tough competition to the grass (Refliaty et al., 2009), as the grass acquire $\mathrm{N}$ from legumes through the decomposition and mineralization of $\mathrm{N}$-rich legume plant litter and $\mathrm{N}$ transfer from the legume to grass (Pirhofer-Walzl et al., 2012). The total $K$ value on SS/CP plot was $>1$ and on SS/CT was $<1$ (Table 3), indicating that S. splendida intercropped with $C$. pubescens contributed to the high productivity per unit of land compared to intercropping with C. ternatea (Yilmaz et al., 2008).

Competition ratio (CR). The value of $\mathrm{CR}_{\mathrm{SS}}$ in $S$. Splendida intercropped with $C$. pubescens and C. ternatea were $>1$ (Table 3), indicating that S. splendida was more competitive than legumes, and caused C. pubescens and C. ternatea growth to be inhibited. Zhang \& Li (2003) reported that interspecific competition may occur when two crops are grown together on the same field. Such competition usually decreases survival, growth or reproduction of at least one species.

Aggressivity (A). Based on Table 3, the positive value of agressivity for S. splendida in both mixed cropping in peatland showed that $S$. splendida was more dominant over C. pubescens and C. ternatea. Dominance of S. splendida was also reflected in the value of $\mathrm{K}$ and $\mathrm{CR}$. This was probably due to more extensive root system of grass than legume (Chen et al., 2004).

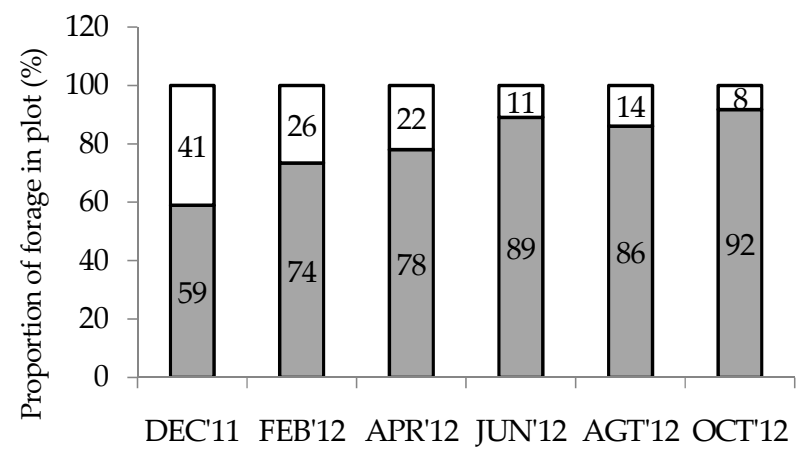

Figure 1a. Proportion of S. splendida ( $\square$ ) and C. pubescens ( $\square$ ) in mix cropping plot at each harvest

\section{Proportion of Grass and Legume on Mix Cropping System}

The proportion of grass to legume in mix cropping system based on SS/CP and SS/CT increased from harvest 1 (December 2011) to harvest 6 (October 2012) (Figure 1a and 1b). The reason for increasing proportion of S. splendida may be attributed to nitrogen fixing ability of legume (Yilmaz et al., 2008) and S. splendida was more competitive and agressive than both the legumes (Table 3). Based on DM yield/yr, the proportion grass to legume on SS/CT plot was higher than the SS/CP plot. The proportion of grass to legume on SS/CT and SS/CP plots were $81.13 \%$ versus $18.87 \%$ and $79.57 \%$ versus $20.43 \%$, respectively. This suggested that $C$. pubescens was more competitive than $C$. ternatea when intercropped with $S$. splendida in peatland.

\section{Nutrient Composition}

Dry matter (DM) content. The DM content of forage was not affected by cropping system but influenced by the forage type (Table 4). The result of study found that DM content of legume was significantly $(P<0.05)$ higher than grass. This result agree with Ajayi et al. (2007) who found that the DM content of grass (Panicum maximum) was lower than legumes (Aeschynomene histrix and Stylosanthes guianensis).

Crude protein (CP) content. The $\mathrm{CP}$ content of forages was not affected by cropping system but influenced by the forage type (Table 4). This result was contrary with those reported by several researchers (Karadag \&

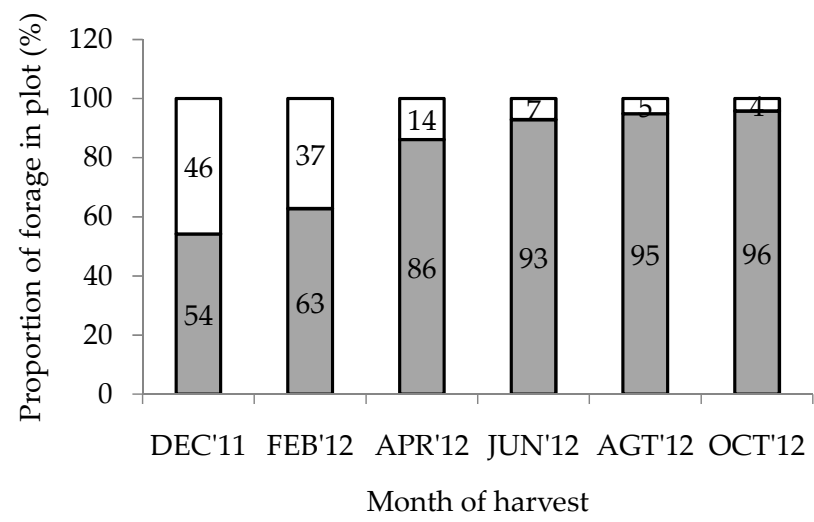

Figure 1b. Proportion of S. splendida ( $\square$ ) and C. ternatea (口) in mixed cropping plot at each harvest 
Table 4. The content of dry matter (DM), crude protein (CP), neutral detergent fibre (NDF), and acid detergent fibre (ADF) of S. splendida, C. pubescens, and C. ternatea under monoculture and mixed cropping

\begin{tabular}{|c|c|c|c|c|}
\hline \multirow{2}{*}{ Forage } & \multirow{2}{*}{$\mathrm{DM}(\%)$} & \multicolumn{3}{|c|}{$\% \mathrm{DM}$} \\
\hline & & $\mathrm{CP}(\%)$ & NDF (\%) & $\operatorname{ADF}(\%)$ \\
\hline S. splendida & $14.8 \pm 0.3^{\mathrm{b}}$ & $7.5 \pm 0.5^{c}$ & $72.4 \pm 2.1^{\mathrm{a}}$ & $37.4 \pm 1.1^{\mathrm{b}}$ \\
\hline S. splendida in C. pubescens intercrop & $14.2 \pm 0.4^{\mathrm{b}}$ & $7.4 \pm 0.9^{c}$ & $68.2 \pm 0.8^{\mathrm{ab}}$ & $36.0 \pm 0.5^{b}$ \\
\hline S. splendida in C. ternatea intercrop & $14.8 \pm 0.7^{\mathrm{b}}$ & $7.4 \pm 0.8^{c}$ & $72.6 \pm 1.2^{\mathrm{a}}$ & $37.6 \pm 0.9^{b}$ \\
\hline C. pubescens & $24.3 \pm 0.4^{\mathrm{a}}$ & $17.5 \pm 2.2^{\mathrm{a}}$ & $67.8 \pm 2.1^{\mathrm{ab}}$ & $45.6 \pm 1.6^{a}$ \\
\hline C. pubescens in S. splendida intercrop & $23.7 \pm 1.3^{\mathrm{a}}$ & $17.4 \pm 0.9^{\mathrm{a}}$ & $66.0 \pm 0.7^{\mathrm{b}}$ & $45.8 \pm 1.7^{\mathrm{a}}$ \\
\hline C. ternatea & $23.0 \pm 1.3^{\mathrm{a}}$ & $14.8 \pm 2.8^{\mathrm{b}}$ & $55.7 \pm 1.4^{\mathrm{c}}$ & $39.2 \pm 0.6^{b}$ \\
\hline C. ternatea in S. splendida intercrop & $24.1 \pm 0.9^{\mathrm{a}}$ & $15.1 \pm 3.1^{\mathrm{b}}$ & $52.1 \pm 8.2^{c}$ & $37.4 \pm 3.9^{\mathrm{b}}$ \\
\hline
\end{tabular}

Note: Mean in the same column with different superscripts differ significantly $(\mathrm{P}<0.05)$.

Buyukburc, 2004; Albayrak et al., 2011; Eskandari, 2012; Njad et al., 2013) who reported that grass intercropped with legume resulted in improved soil fertility through the addition nitrogen by fixation and excretion from the legume component and also increased CP content of nearby grass. The $\mathrm{CP}$ content of $S$. splendida that were planted in peatland was slightly lower than the average CP content of $S$. splendida reported by Heuzé \& Tran (2012) who showed that the CP content of S. splendida was $9.1 \%$. The CP content of C. pubescens and C. ternatea were higher significantly $(\mathrm{P}<0.05)$ than $S$. splendida. This indicated that legumes have a higher nutrient content than grass (Albayrak et al., 2011) particularly CP content (Paulson et al., 2008). These study also showed that $\mathrm{CP}$ content of both legumes planted in peatland was generally lower than those found by several researches. Evitayani et al. (2004), Omele et al. (2011) and Martens et al. (2012) reported that CP content of C. pubescen was $18.9 \%, 25.5 \%$, and $23.6 \%$, respectively. However, Mahala et al. (2012), Nasrullah et al. (2003) and Heinritz et al. (2012) reported that CP content of C. ternatea was $17 \%, 18.28 \%$, and 19\%, respectively. These evidences showed that CP content is influenced by forage type, environmental condition and land condition (Jayanegara \& Sofyan, 2008). Soil conditions will affect the availability of nutrients and soil organic matter (Sabrina et al., 2013) which led to varied growth and forage quality.

S. splendida/C. pubescens and S. splendida/C. ternatea mixed cropping did not increase $\mathrm{CP}$ production per unit area of land. Even, the CP production of SS/CT plot tended to be lower than SS plot (Table 5). This was due to the low dry matter production of C. pubescens and C. ternatea intercropped with S. splendida (Table 1).

Neutral detergent fibre (NDF). Based on Table 4, the NDF content of forages was not affected by cropping system but influenced by the forage type. NDF content of C. ternatea $(52.1 \%-55.7 \%)$ obtained in this study were significantly $(\mathrm{P}<0.05)$ lower than NDF content of $S$. splendida (68.2\%-72.6\%) and C. pubescens (66\%-67.8\%). In general, NDF content of C. pubescens was lower than of $S$. splendida. These results indicated that the NDF content of legumes was generally lower than those of grass. This was attributed to the different characteristics
Table 5. Crude protein (CP) production per plot of forages based on cropping system

\begin{tabular}{llcc}
\hline \multirow{2}{*}{$\begin{array}{l}\text { Cropping } \\
\text { system }\end{array}$} & \multirow{2}{*}{ Plot } & \multicolumn{2}{c}{ CP production } \\
\cline { 3 - 4 } & & (g/plot/harvest) & (kg/plot/yr) \\
\hline Monoculture & S. splendida (SS) & 207 & 1.243 \\
& C. pubescens (CP) & 213 & 1.280 \\
& C. ternatea (CT) & 261 & 1.567 \\
Mixture & SS/CP & 223 & 1.339 \\
& SS/CT & 157 & 0.943 \\
\hline
\end{tabular}

of the cell wall (Paulson et al., 2008). Legumes have particularly large amounts of pectin in primary walls, resulting in more pectin in legume forages than grasses in both leaves and stems (Jung \& Casler, 2006; Paulson et al., 2008). Most tissue types in grasses lignify as they mature whereas most legume tissues do not lignify (Paulson et al., 2008). Based on the value of NDF, the C. ternatea intake was higher than S. splendida and C. pubescens when fed to ruminants. NDF value reflects the total fraction of fibre (cellulose, hemicellulose, and lignin). Thus, the NDF content will be negatively correlated to the intake (Mertens, 2009). When NDF content of forage is high, it causes a decrease in intake (Milic et al., 2011). The average NDF content of S. splendida, C. Pubescens, and $C$. ternatea found in this study were generally higher than the findings of other researchers. Heuzé \& Tran (2012) reported that NDF content of S. splendida was 69.5\%. Evitayani et al. (2004) reported that NDF content of C. pubescens that grows in North Sumatra was 51.1\%. Nasrullah et al. (2003) found that NDF content of C. ternatea which grows naturally in South Sulawesi was $42.30 \%$. Variation in NDF content is caused by genotype and environmental factors (Adesogan et al., 2002; Nasrullah et al., 2003; Evitayani et al., 2004).

Acid detergent fibre content. This study found that the ADF content of forages was not affected by cropping system but influenced by the forage type (Table 4 ). This was probably due to the relative stability of the cellulose content of grasses and legumes (Weiss et al., 2002). The 
results showed that the ADF content of C. pubescens was significantly $(\mathrm{P}<0.05)$ higher than $C$. ternatea and S. splendida. In relation to the digestibility C. pubescens have lower digestibility than C. ternatea and S. splendida (Albayrak et al., 2011). The results also illustrated that the ADF content of legumes was not always lower than the grass. Grasses and legumes are likely to have the same ADF value, but NDF content of grass generally always substantially higher than the legume (Weiss et al., 2002).

\section{CONCLUSION}

Mixed cropping in peatland (type sapric) does not influence productivity and nutritive value of S. splendida, C. Pubescens, and C. ternatea. S. splendida is more effective in exploiting environmental resources when intercropped with $C$. pubescens compared C. ternatea on peatland. Based on value of $\mathrm{K}, \mathrm{CR}$, and $\mathrm{A}, \mathrm{S}$. splendida is more competitive and dominant than $C$. pubescens and $C$. ternatea on peatland.

\section{REFERENCES}

Adesogan, A. T., L. E. Sollenberger, Y. C. Newman, \& J. M. B. Vendramini. 2002. Factors Affecting Forage Quality. Agronomy Department, Florida Cooperative Extension Service, Institute of Food and Agricultural Sciences, University of Florida. edis.ifas.ufl.edu/pdffiles/AG/AG16100. pdf. [1 September 2013].

Agus, F. \&. I. G. M. Subiksa. 2008. Lahan Gambut: Potensi untuk Pertanian dan Aspek Lingkungan. Balai Penelitian Tanah. Badan Penelitian dan Pengembangan Pertanian. Bogor. Indonesia.

Ajayi, F. T., O. J. Babayemi, \& A. A. Taiwo. 2007. Effect of Stylosanthes guianensis and Aeschynomene histrix on the yield, proximate composition and in-situ dry matter and crude protein degradation of Panicum maximum (Ntchisi). Lives. Res. for Rur. Dev. 19 (3). www.lrrd.org/lrrd19/3/ajay19032. htm. [24 July 2013].

Albayrak S., M. Turk, O. Yuksel, \& M. Yilmaz. 2011. Forage yield and the quality of perennial legume-grass mixtures under rainfed conditions. Not. Bot. Hort. Agrobot. Cluj. 39:114-118.

AOAC. 2005. Official Methods of Analysis. AOAC International. $18^{\text {th }}$ ed. Assoc. Off. Anal. Chem, Airlington, USA.

Banik, P., A. Midya, B. K. Sarkar, \& S. S. Ghose. 2006. Wheat and chickpea intercropping systems in an additive series experiment: Advantages and weed smothering. Eur. J. Agron. 24: 325-332. http://dx.doi.org/10.1016/j.eja.2005.10.010

Chen, C., M. Westcott, K. Neill, D. Wichman, \& M. Knox . 2004. Row configuration and nitrogen application for barley-pea intercropping in Montana. Agron. J. 96: 1730-1738. http://dx.doi.org/10.2134/agronj2004.1730

Dhalika, T., Mansyur, H. K. Mustafa, \& H. Supratman. 2006. Proportion of African star grass and sentro in mix pasture system on production and quality of forages. J. Ilmu Ternak. 6: 163-168.

Dhima, K. V., A. A. Lithourgidis, I. B. Vasilakoglou, \& C. A. Dordas. 2007. Competition indices of common vetch and cereal intercrops in two seeding ratio. Field Crop Res. 100: 249-256. http://dx.doi.org/10.1016/j.fcr.2006.07.008

Eskandari, H. 2012. Yield and quality of forage produced in intercropping of maize (Zea mays) with cowpea (Vigna sinensis) and mungbean (Vigna radiate) as double cropped. J. Basic. Appl. Sci. Res. 2: 93-97.
Evitayani, L. Warly, A. Fariani, T. Ichinohe, \& T. Fujihara. 2004. Study on nutritive value of tropical forages in North $\mathrm{Su}-$ matra, Indonesia. Asian-Aust. J. Anim. Sci. 17: 1518-1523.

Forrester, D. I., J. Bauhus, A. L. Cowie, \& J. K. Vanclay. 2006. Mixed-species plantations of Eucalyptus with nitrogenfixing trees: A review. Forest Ecol. Manag. 233: 211-230. http://dx.doi.org/10.1016/j.foreco.2006.05.012

Heinritz, S. N., S. Hoedtke, S. D. Martens, M. Peters, \& A. Zeyner. 2012. Evaluation of ten tropical legume forages for their potential as pig feed supplement. Lives. Res. for Rur. Dev. 24 (1). http://www.lrrd.org.lrrd24/1/cont2401.htm. [28August 2013].

Heuzé, V. \& G. Tran. 2012. Giant setaria (Setaria sphacelata var. splendida). Feedipedia.org. http://www.feedipedia.org/ node/380. [30 Juli 2013].

Jayanegara, A. \& A. Sofyan. 2008. Penentuan aktivitas biologis tanin beberapa hijauan secara in vitro menggunakan hohenheim gas test dengan polietilen glikol sebagai determinan. Med. Pet. 31: 44-52.

Jung, H. G. \& M. D. Casler. 2006. Maize stem tissues: Cell wall concentration and composition during development. Crop. Sci. 46:1793-1800. http://dx.doi.org/10.2135/cropsci2005.020085

Karadag, Y. \& U. Buyukburc. 2004. Forage qualities, forage yields and seed yields of some legume-triticale mixtures under rainfed conditions. Acta Agri. Scan. B-S P 54: 140148.

Mahala, A.G., S.O. Amasiab, Monera, A. Yousif, \& Elsadig. 2012. Effect of plant age on DM yield and nutritive value of some leguminous plants (Cyamopsis tetragonoloba, Lablab purpureus and clitoria (Clitoria ternatea). Int. Res. J. Agric. Sci. 2: 502-508.

Mahapatra, S. C. 2011. Study of grass-legume intercropping system in term of competition indices and monetary advantage index under acid lateritic soil of India. Am. J. Exp. Agric. 1: 1-6.

Martens, D., S. D. T. T. Tiemann, J. Bindelle, M. Peters, \& C. E. Lascano. 2012. Alternative plant protein sources for pigs and chickens in the tropics-nutritional value and constraints: A review. J. Agr. Rural Develop. Trop. Subtrop. 113: 101-123.

Marty, C., A. Pornon, N. Escaravage, P. Winterton, \& T. Lamaze. 2009. Complex interactions between a legume and two grasses a subalpine meadow. Am. J. Bot. 96: 18141820. http://dx.doi.org/10.3732/ajb.0800405

Mertens, D. R. 2009. Impact of NDF content and digestibility on dairy cow performance. WCDS Advance in Dairy Technology. 21: 191-201.

Milić, D., Đ. Karagić., S. Vasiljević., A. Mikić., B. Mijić, \& S. Katić. 2011. Leaf and stem chemical composition of devergent alfalfa cultivars. Biotechnology in Animal Husbandry 27: 1505-1511. http://dx.doi.org/10.2298/BAH1104505M

Mucheru-Muna, M., P. Pypers, D. Mugendi , J. Kung'u, J. Mugwe, R. Merckx, \& B.Vanlauwe. 2010. A staggered maize-legume intercrop arrangement robustly increases crop yields and economic returns in the highlands of Central Kenya. Field Crops Res. 115: 132-139. http://dx.doi. org/10.1016/j.fcr.2009.10.013

Mutimura, M. \& T. M. Everson. 2012. On-farm evaluation of improved Brachiaria grass in low rainfall and aluminium toxicity prone areas of Rwanda. Int. J. Biodvers. Conserv. 4: 137-154.

Nasrullah., M. Niimi, R. Akashi, \& O. Kawamura. 2003. Nutritive evalution of forage plants grown in South Sulawesi, Indonesia. Asian-Aust. J. Anim. Sci. 16: 693-701.

Njad, A. K., S. Mohammadi, N. Khaliliaqdam, M. P. Yousef, \& N. J. Nejad. 2013. Barley-clover intercropping: advantages and competition indices. Adv. Crop. Sci. 13: 497-505.

Noula, F. S., O. O. Akinbamijo, O. B. Smith, \& V. S. Pandey. 
2004. Horticultural residues as ruminant feed in per-urban area of the Gambia. Livestock Research for Rural Development 16 (6). http://www.cipav.org.co/lrrd//rrd16/6/noua 16037.htm. [20 July 2013].

Omole, A. J., A. M. Ogungbesan, J. A. Fayenuwo, \& Y. A. Popoola. 2011. Comparative utilization of Centrosema pubescens or Mucuna purensis as a substitute for pawpaw leaf by growing snails. Lives. Res. for Rur. Dev. 23 (6). http:// www.lrrd.org/lrrd23/3/omol23063.htm. [18 August 2013].

Oseni, T. O. 2010. Evaluation of sorghum-cowpea intercrop productivity in savanna agro-ecology using competition indices. J. Agric. Sci. 2: 229-234.

Paulson, J., H. Jung, M. Raeth-Knight, \& J. Linn. 2008. Grass vs Legume Forage for Dairy Cattle. University of Minnesota Extension. http://www.extension.umn.edu [30 Juli 2013].

Peyraud, J. L., A. Le Gall, \& A. Lüscher. 2009. Potential food production from forage legume-based-systems in Europe: An overview. Irish J. Agric. Food Res. 48: 115-135.

Pozdisek, J., B. Henriksen, A. Ponizil, \& A. K. Loes. 2011. Utilizing legume-cereal intercropping for increasing self-suffiency on organic farms in feed for monogastric animal. Agron. Res. 9: 343-356.

Pirhofer-Walzl, K., J. Rasmussen, H. Høgh-Jensen, J. Eriksen, K. Søegaard, \& J. Rasmussen. 2012. Nitrogen transfer from forage legumes to nine neighbouring plants in a multi-species grassland. Plant Soil. 350:71-84. http://dx.doi. org/10.1007/s11104-011-0882-z

Refliaty., Y. Farni, \& S. Intan. 2009. Pengaruh leguminosa cover crop (LCC) terhadap sifat fisik ultisol bekas alang-alang dan hasil jagung. J. Agronomi 13: 51-56.
Sabrina D.T., M. M. Hanafi, A.W. Gandahi, M. T. M. Mohamed, \& N. A. A. Aziz. 2013. Effect of mixed organicinorganic fertilizer on growth and phosphorus uptake of setaria grass (Setaria splendida). Aust. J. Crop Sci. 7:75-83.

Thorsted, M. D., J. Weiner, \& J. E. Olesen. 2006. Above and below-ground competition between intercropped winter wheat Triticum aestivum and white clover Trifolium repens. J. Appl. Ecol. 43: 237-245. http://dx.doi.org/10.1111/j.13652664.2006.01131.x

Van Soest, P. J., J. B. Robertson, \& B. A Lewis. 1991. Methods for dietary fiber, neutral detergent fiber and non-starch polysaccharides in relation to animal nutrition. J. Dairy Sci. 74: 3583-3593. http://dx.doi.org/10.3168/jds.S00220302(91)78551-2

Vasileva, V. \& E. Vasilev. 2012. Study on productivity of some legume crops in pure cultivation and mixtures. Agric. Conspec. Sci. 77: 91-94.

Weiss, W. P., M. L. Eastridge, \& J. F. Underwood. 2002. Forages for Dairy Cattle. Ohio State University Extension. http:// ohioline.osu.edu/as-fact/0002.html. [19 August 2013].

Yilmaz, S., M. Atak, \& M. Erayman. 2008. Identification of advantage of maize-legume intercropping over solitary cropping through competition indices in the East Mediterranean Region. Turk. J. Agric. For. 32: 111-119.

Zhang, F. \& L. Li. 2003. Using competitive and facilitative interactions in intercropping system enhances crop productivity and nutrient-use efficiency. Plant Soil 248: 305-312. http://dx.doi.org/10.1023/A:1022352229863 